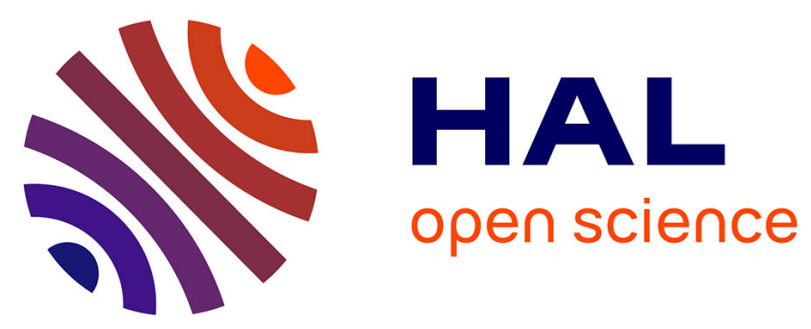

\title{
Apoptosis as a mechanism of germ cell loss in mature stallions
}

N. Heninger, Christophe Staub, T. Blanchard, D. Varner, C. Love, D. Forrest, L. Johnson

\section{- To cite this version:}

N. Heninger, Christophe Staub, T. Blanchard, D. Varner, C. Love, et al.. Apoptosis as a mechanism of germ cell loss in mature stallions. Theriogenology, 2002, 58, pp.373-376. hal-02673918

\section{HAL Id: hal-02673918 https://hal.inrae.fr/hal-02673918}

Submitted on 31 May 2020

HAL is a multi-disciplinary open access archive for the deposit and dissemination of scientific research documents, whether they are published or not. The documents may come from teaching and research institutions in France or abroad, or from public or private research centers.
L'archive ouverte pluridisciplinaire HAL, est destinée au dépôt et à la diffusion de documents scientifiques de niveau recherche, publiés ou non, émanant des établissements d'enseignement et de recherche français ou étrangers, des laboratoires publics ou privés. 


\title{
Apoptosis as a mechanism of germ cell loss in mature stallions
}

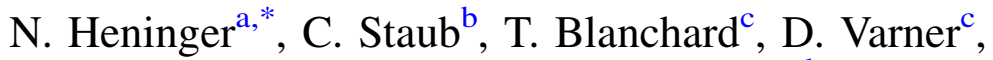 \\ C. Love ${ }^{\mathrm{c}}$, D. Forrest ${ }^{\mathrm{a}}$, L. Johnson ${ }^{\mathrm{b}}$ \\ ${ }^{a}$ Department of Animal Science, Texas A\&M University, College Station, TX 77843, USA \\ ${ }^{\mathrm{b}}$ Department of Veterinary Anatomy and Public Health, Texas A\&M University, College Station, TX 77843, USA \\ ${ }^{\mathrm{c}}$ Department of Large Animal Medicine and Surgery, Texas A\&M University, College Station, TX 77843, USA
}

\section{Introduction}

Germ cell losses occur during spermatogenesis in most male mammals, with losses during spermatocytogenesis and meiosis accounting for substantial decreases in daily sperm production potential in the stallion [1]. Apoptosis, or programmed cell death, is widely accepted as being the primary mechanism for removing germ cells from the seminiferous epithelium in most species. Heninger et al. [2] implicated apoptosis as the mechanism of germ cell loss during initiation of spermatogenesis in the pubertal stallion. The purposes of this study were to: (1) determine if apoptosis of germ cells occurred in adult stallions with normal testes, and (2) describe apoptotic rates by stage of the seminiferous epithelial cycle in stallion testes in which apoptosis of germ cells occurred.

\section{Materials and methods}

Testes were obtained by castration in June 2001, from eight mature (4-17 years) lightbreed stallions that had previously been determined to have normal testes size and semen quality. Testes were weighed, and parenchyma was sectioned and immersion-fixed in $4 \%$ paraformaldehyde, then transferred to $70 \%$ ethyl alcohol for $24 \mathrm{~h}$ prior to embedding in paraffin. Immunohistochemical apoptotic detection was performed on 3- $\mu \mathrm{m}$ paraffin sections mounted on Superfrost plus ${ }^{\circledR}$ glass slides using an Apoptag ${ }^{\circledR}$ peroxidase detection kit S7100 (TUNEL) (Intergenco, Purchase, NY, USA). Slides were deparaffinized and tissue was permeabilized with proteinase $\mathrm{K}(20 \mu \mathrm{g} / \mathrm{ml})$ for $15 \mathrm{~min}$. Endogenous peroxidases were quenched in $3 \%$ hydrogen peroxide for 5 min. Incorporation of digox-

\footnotetext{
* Corresponding author.

E-mail address: nheninger@neo.tamu.edu (N. Heninger).
} 
igenin with TdT enzyme was performed at $37^{\circ} \mathrm{C}$ for $1 \mathrm{~h}$ in a humidity chamber followed by incubation with anti-digoxigenin peroxidase conjugate for $30 \mathrm{~min}$ at room temperature. Color development was obtained using $0.05 \%$ diaminobenzidine (DAB) in PBS for 10 min. Slides were stained with periodic acid-Schiff (PAS) stain for $10 \mathrm{~min}$ and counterstained with toluidine blue (1:100) for $1 \mathrm{~min}$, then a cover slip was applied with Permount mounting media. Commercially available rat regressing mammary slides were used as positive controls.

To confirm Apoptag ${ }^{\circledR}$ labeling of apoptotic germ cells, a 4-year-old thoroughbred stallion with normal testicular size and semen quality was unilaterally castrated. Following unilateral castration, a GnRH-agonist (four $2.1 \mathrm{mg}$ implants of deslorelin) was administered, and the remaining testis was removed 10 days later when induced apoptotic rate was expected to be high. Testicular samples were fixed and prepared as described earlier, and apoptotic rates of pre- and post-treatment testes were compared in adjacent 3- $\mu \mathrm{m}$ serial sections. One hundred germ cells staining positive for apoptosis (Apoptag ${ }^{\circledR}$ assay) were evaluated for pyknosis in the adjacent PAS-toluidine blue-stained section.

One hundred cross-sections of seminiferous tubules for each testis were classified by stage of seminiferous epithelial cycle (I-VIII) according to Johnson et al. [3] except that a PAS staining technique was used for more accurate assessment of acrosomal morphology by light microscopy. Tubules containing at least $75 \%$ of a respective stage were counted. The apoptotic rate was expressed as the number of apoptotic germ cells in a given tubule per 100 Sertoli cell nuclei to compensate for histological shrinkage and tubule diameter.

\section{Results}

A three-fold increase in number of apoptotic germ cells per 100 Sertoli cells was detected in pre-treatment (7.85) versus post-treated (24.08) testes of the 4-year-old thoroughbred stallion. Pyknotic nuclei were evident in 97 of 100 Apoptag ${ }^{\circledR}$-labeled germ cells. No differences in number of Apoptag ${ }^{\circledR}$-labeled germ cells per 100 Sertoli cell nuclei were detected between right and left testes of each of the remaining eight horses $(P>0.10)$, so data from both testes were pooled to calculate mean apoptotic rate. Mean

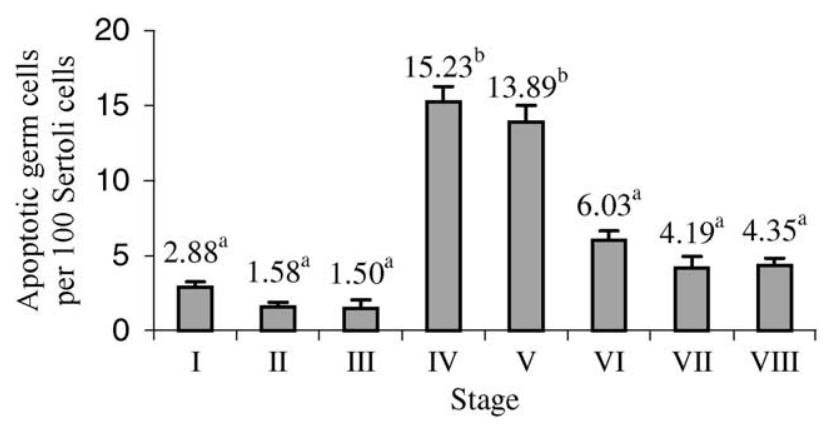

Fig. 1. Average number of apoptotic testicular germ cells per 100 Sertoli cells. Means with different superscripts differ significantly $(P<0.0001)$. 


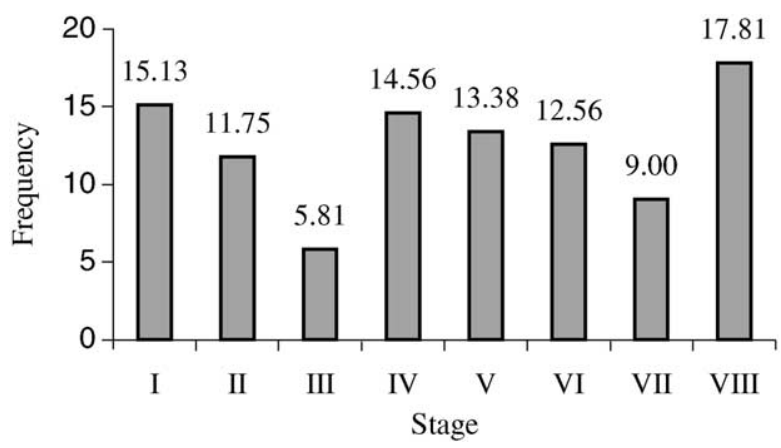

Fig. 2. Mean frequency of seminiferous epithelial stages in reproductively normal stallions $(n=8)$.

number of apoptotic germ cells per 100 Sertoli cell nuclei ranged from 1.50 to 15.23 for the eight stallions (Fig. 1). Frequency of seminiferous epithelial stages (Fig. 2) were similar to those reported by Swierstra et al. [4]. Number of Sertoli cell nuclei did not differ between seminiferous epithelial stages $(P=0.85)$. Mean numbers of apoptotic germ cells per 100 Sertoli cell nuclei were higher in stages IV and V of the seminiferous epithelial cycle than in other stages $(P<0.001$; Fig. 1); however, apoptosis occurred in all stages of the cycle.

\section{Discussion}

Apoptosis appears to be the mechanism responsible for germ cell death, and is thereby considered a normal process in stallion testes. Stage-specific apoptosis is a widely accepted occurrence in the testes of most mammals. Our results support that of others, which state that germ cell apoptosis coincides with mitotic [5] and meiotic [6] peaks. Apoptosis of spermatocytes and spermatogonia may, in part, explain the relative inefficiency of the proliferative and meiotic phases of spermatogenesis in the stallion. Apoptosis may also serve a regulatory function to maintain an optimal germ cell:Sertoli cell ratio [7]. The morphology of apoptosis is defined by cellular shrinkage, chromatin and cytoplasmic condensation, and finally, fragmentation of chromatin. Our study confirms that the immunohistochemical labeling of fragmented DNA by free $3^{\prime}-\mathrm{OH}$ end-labeling is specific for these pyknotic nuclei. Apoptosis occurs in each of the stages of spermatogenesis in the stallion, with the lowest levels of apoptosis occurring in stages I-III, VI and VII, and the highest levels during meiotic stages IV and V of the seminiferous epithelial cycle. It appears that meiotic divisions occurring in stage IV in stallion spermatogenesis is a crucial checkpoint for germ cell development. The higher rate of apoptosis in stage $\mathrm{V}$ may be due to the fact that degenerating cells from the previous stage have not been cleared by the Sertoli cells.

The relationship of apoptosis to cases of clinical male idiopathic infertility remains unclear. Establishing a basal level of germ cell apoptosis during normal spermatogenesis in the stallion is a critical step towards defining subfertility/infertility in the stallion. Further research is required to understand the events leading to germ cell degeneration. 


\section{Acknowledgements}

Funded in part by the Link Equine Research Endowment, Texas A\&M University.

\section{References}

[1] Johnson L, Varner DD, Roberts ME, Smith TL, Keillor GE, Scrutchfield WL. Efficiency of spermatogenesis: a comparative approach. Anim Reprod Sci 2000;60/61:471-80.

[2] Heninger NL, Donnelly C, Staub C, Blanchard TL, Varner D, Forrest DW, et al. Apoptosis as a mechanism of germ cell loss in stallions. Proc Am Soc Anim Sci JAS 2001;79(1):229.

[3] Johnson L, Hardy VB, Martin MT. Staging equine seminiferous tubules by Nomarski optics in unstained histologic sections and in tubules mounted in toto to reveal the spermatogenic wave. Anat Rec 1990;27:167-74.

[4] Swierstra EE, Gebauer MR, Pickett BW. Reproductive physiology of the stallion. I. Spermatogenesis and testis composition. J Reprod Fertil 1974;40:113-23.

[5] Blanco-Rodriguez J, Martinez-Garcia C. Spontaneous germ cell death in the testis of the adult rat takes the form of apoptosis: re-evaluation of cell types that exhibit the ability to die during spermatogenesis. Cell Prolif 1996;29:13-31.

[6] Kon Y, Horikoshi H, Endoh D. Metaphase-specific cell death in meiotic spermatocytes in mice. Cell Tissue Res 1999;296:359-69.

[7] Johnson L. A new approach to quantification of Sertoli cells that avoids problems associated with the irregular nuclear surface. Anat Rec 1986;214:231-7. 